\title{
THE "FLESH AND BLOOD" OF HISTORY \\ LITTLE, BROWN'S "LIBRARY OF AMERICAN BIOGRAPHY" SERIES IN THE SURVEY CLASS A REVIEW ESSAY
}

\author{
Raymond C. Bailey \\ Northern Virginia Community College
}

In his famous essay on the role of the hero in history, Thomas Carlyle maintained that history was merely the "Biography of Great Men."l Few historians today would give an uncritical acceptance to such sentiments. Yet biography has always been one of the most popular forms of historical writing, among scholars almost as much as among the general public. History is, after a11, at bottom the chronicle of people. Studying the role of Winston Churchill, for example, does not alone convey a complete understanding of World War II, but no one can fully understand that war without coming to grips with the Prime Minister who hurled defiance at Hitler in 1940 and rallied his people to hang on until help arrived. 2

Biographies have thus always been popular, among professors and students alike, as supplementary reading assignments for survey classes. As with other books, however, the value of any particular biography intended for classroom use will depend upon four considerations: it must be reasonably brief, well-written, founded upon sound scholarship, and relate the subject to the broad perspectives of our history. While a number of such books are available, for American history Little, Brown's "Library of American Biography" series offers a particularly wide selection. After a period of relative neglect in the 1960s, Little, Brown has recently shown renewed interest in promoting the series and adding new titles to it. As a result professors have several outstanding new selections for consideration.

One of the most attractive of these recent additions is Alden T. Vaughan's American Genesis: Captain John Smith and the Founding of Virginia (1975). The book is based upon thorough primary research and a familiarity with the related secondary works. While the author obviously admires his subject and enjoys telling the story, this is a judicious and perceptive account. In the English colonization effort John Smith played a critical and frequently controversial role as adventurer and publicist. Although John Smith was actually resident in Virginia only from 1607 to 1609, Vaughan's narrative ranges over a much broader span, from an able discussion of why colonization occurred to the reasons for royalization of Virginia in 1624. Much that was fundamental to American development began in that period, including paradoxically both growing colonial self-government and the introduction of Negro slavery. Indeed, Vaughan's examination of how and why slavery took root in Virginia is perhaps the best brief discussion of this complex and controversial topic now available. Similarly, his treatment of Indian-white relations makes an excellent introduction to that subject. Professors interested in enhancing student understanding of our early history should give serious consideration to this book.

Several other recent titles--especially David P. Thelen's Robert LaFollette and the Insurgent Spirit (1976) and Joan Hoff Wilson's Herbert Hoover: The

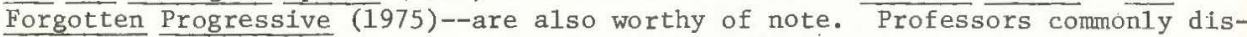
cuss the better-known Progressives, Roosevelt and Wilson in particular, in some depth; an assigned reading about LaFollette and his work in Wisconsin and at the national level thus makes an appealing supplement. Thelen's book is quite readable, and his interpretation of Progressivism here and elsewhere, stressing the broad base and consumer orientation of the movement, is very much in tune with recent scholarship. Wilson's study of Herbert Hoover, also based upon thorough research, has been described as perhaps the best new book available on a man whose reputation among historians has grown substantially in the past few years. 3 In addition to increasing student understanding of the $1920 \mathrm{~s}$ and $30 \mathrm{~s}$, the book can also lead to discussion of today's "welfare state," for the 
questions and criticisms raised by Hoover will seem quite timely in the current political climate.

Among other recent additions to the series, Harold Livesay's Andrew Carnegie and the Rise of Big Business (1975) and Samuel Gompers (1978)* might appeal to historians teaching about the late nineteenth century. Andrew Jackson and the Search for Vindication (1976), by James C. Curtis, provides a generally critical look at old Hickory and could help balance the more common, generally favorable popular and scholarly interpretation. Curtis wrote from a psychoanalytical perspective, however, which has not gone without criticism. 4

Nor should professors confine their interest to these new volumes. While some biographies in the series are now almost a quarter-century old, as a rule they have aged remarkably well. Edmund S. Morgan's The Puritan Dilemma: The Story of John Winthrop (1958) remains the best brief introduction to the subject. I stili assign it to my students; in addition to strengthening their general understanding of puritanism, the book stimulates worthwhile discussion about the "dilemma"--what obligations does the individual have to society? This, in turn, helps students to realize that the study of history is "relevant" to the present after all. Similarly, Russell B. Nye's William Lloyd Garrison and the Humanitarian Reformers (1955) can help students learn about the antislavery movement in particular and about the nature of social reform in general. In like manner the story of Woodrow Wilson's efforts at transforming the nation and the world to fit his moral convictions is as timely today as ever, and John M. Blum's Woodrow Wilson and the Politics of Morality (1956) is unsurpassed by any other short treatment.

There are some rather inexplicable gaps in the series. Henry Clay, Daniel Webster, and Stephen A. Douglas have all been the subjects of excellent works which illuminate the importance of these giants from America's "Silver Age."5 But volumes on Calhoun and Lincoln, as well as on most of the Revolutionary generation of leaders, have never been added to the series. Moreover, at present Booker $T$. Washington is the only black represented in the series, 6 and none of the biographies so far are about women. Recent promotional literature from the publisher, however, promises forthcoming volumes on Frederick Douglass, Abigal Adams, and Elizabeth Cady Stanton. All will be eagerly welcomed.

Certainly there are other fine biographies suitable for classroom adoption available from other publishers. One thinks immediately of Robert Remini's Andrew Jackson, for example.7 Each professor can probably add several other favorites to such a list. I used William and Bruce Catton's Two Roads to Sumter for several quarters and received a quite favorable response. 8 Several colleagues have recommended the brief examinations of Lincoln by Richard Current and David Donald, along with John Blum's The Republican Roosevelt.9 I suspect that these might make excellent assignments also. Yet as a series the "Library of American Biography" collection is without peer. Other volumes in the series not discussed in this essay also merit serious attention; Oscar Handlin's Al Smith and His America (1958), for example, remains a popular account. Historians have frequently been accused--sometimes with justification--of writing only for each other. ${ }^{10}$ The Little, Brown Series illustrates that we can in fact speak successfully to a wider audience as well.

*The biography of Gompers is reviewed more extensively elsewhere in this issue. --Ed. 


\section{NOTES}

${ }^{1}$ Thomas Carlyle, On Heroes, Hero-Worship, and the Heroic in History (New York, 1852). This quotation came from a portion of that work reprinted in The Varieties of History, ed. Fritz Stern (Cleveland, 1956), 103.

2

${ }^{2}$ See the excellent discussions about the role of individuals in shaping history in Car1 G. Gustavson, A Preface to History (New York, 195.5), ch. 10; Sidney Hook, The Hero in History: A Study in Limitation and Possibility (New York, 1943); and Edward H. Carr, What is History? (New York, 1961). In contrast to Carlyle's statement, an excellent recent book on the study and teaching of history maintains that biography "qualifies as history . . only insofar as men are not isolated from the greater context of historical events." Lester D. Stephens, Probing the Past: A Guide to the Study and Teaching of History (Boston, 1974), 17-18.

${ }^{3}$ Thelen's The New Citizenship: Origins of Progressivism in Wisconsin (Columbia, Missouri, 1972) is an especially important book. For a summary of recent work about Hoover, see the review essay by Robert H. Zieger, "Herbert Hoover: A Reinterpretation," American Historical Review, LXXXI (October, 1976), 800-810.

${ }^{4}$ See the review by Charles M. Wiltse in American Historical Review, LXXXII (June, 1977), 743-744.

5

Clement Eaton, Henry Clay and the Art of American Politics (1957); Richard N. Current, Daniel Webster and the Rise of National Conservatism (1955); Gerald M. Capers, Stephen A. Douglas: Defender of the Union (1959).

6

Samuel R. Spencer, Jr., Booker T. Washington and the Negro's Place in American Life (1955).

7 (Harper and Row, 1969 [originally published in 1966]).

${ }^{8}$ (New York, McGraw-Hill, 1963). This book traces the coming of the Civil War through the lives of Lincoln and Jefferson Davis.

9 Richard N. Current, The Lincoln Nobody Knows (New York, Hill and Wang, 1958); David Donald, Lincoln Reconsidered (New York, Vintage Books, 1961 [originally published in 1956]); John M. Blum, The Republican Roosevelt (Cambridge, Massachusetts, Harvard University Press, 1954).

${ }^{10}$ See, for example, the stimulating essay by Samuel Eliot Morison, "History As a Literary Art," in Sailor Historian: The Best of Samuel Eliot Morison, ed. Emily Morison Beck (Boston, 1977), 383-393. 